\title{
THE INVESTIGATION OF EFFECTIVENESS OF INDIVIDUAL AND GROUP FORMS OF LEARNING A FOREIGN LANGUAGE
}

\section{IN KAZAKHSTAN}

\author{
Saltanat Meiramova
}

International Cooperation and Multilingual Education Development Centre,

S.Seifullin Kazakh Agro Technical University,

Pobeda Street 62, Astana, Kazakhstan

E-mail address: meiramovas@gmail.com

\author{
Akniet Zhanysbayeva \\ Faculty of Philology, L.N.Gumilyov Eurasian National University, \\ Munaitpassova Street 5, Astana, Kazakhstan \\ E-mail address: akniet.zhanysbayeva@mail.ru
}

\begin{abstract}
It is known that the language classroom is the place where teachers and learners come together for interaction and students can learn English in natural settings. Group work is a teaching strategy at all levels of education and researchers have observed that group based assignments and discussions are a common feature of tertiary education. The effective use of group work in the language class can provide a valuable learning experience to students and give them the opportunity to practically experience the language exposure of the ideas presented and strengthen their learning.

In this regard, this paper attempts to identify the efficiency of individual and group work teaching strategy of the students to excel at foreign language learning. Then, the paper aims to define the effect of individual and group work of students' value participation in academic communication. Finally, the paper tries to determine the most effective methods for working in a group and individually with the help of the data obtained with the help of a purpose-designed questionnaire to assess their preference for different teaching methods.

Keywords: Individual and group work, Kazakhstan, teaching strategy, learning technique.
\end{abstract}

\section{INTRODUCTION}

There are three different types of teaching methods identified through all different curricula in Kazakhstan which can distinguish: individual work, group work and class work (Johnson, Johnson, Zhaitapova, Nametkulova). In this article we attempt to investigate individual and group work of techniques in learning. The most popular forms of any foreign language learning in Kazakhstani schooling are group and 
individual lessons due to curriculum reconsideration with support from Cambridge University focusing on critical thinking and Content and Language Integrative Learning. Practice shows that both methods are effective, their effectiveness depends on the purpose for learning a foreign language. Language is a social phenomenon. We need it to communicate with people, for this reason, a group lesson is natural. While learning in a group, it is possible to achieve two goals: to learn English and, overcome the fear of communicating in a foreign language. Group work becomes more and more important within many occupations, as cooperation with others also becomes more crucial.

The relevance of this work is determined by the fact that the problem of the choice of methods and foreign language teaching techniques could effect on language proficiency. The importance of considering the methods and techniques in foreign languages teaching is proved by several arguments.

Firstly, it is obvious that the methodology of foreign languages learning and teaching in schools needs to be revised to find the effective ways of innovative teaching methods and techniques using.

Secondly, it is recognised that learning languages should be an integral part of public education to promote desirable attributes like creativity, critical thinking, and problem solving. In this context every teacher should identify the teaching methods to teach students to communicate their thoughts while being creative and reflective in their academic process. In addition, students have to define learning strategies be excited to appreciate the language education as a source of new knowledge and personal fulfillment.

Thirdly, Chirac, H., Hempel, E. (2014) advocate for group work function both as an objective (i.e. learning collaborative abilities) and as the means (i.e. a base for academic achievement) or both from the learning perspectives. In this context, teachers have to understand their role in group formation, group support and follow up mechanisms for discovery and thinking. Next, teachers should be motivated to integrate group working methods in their classroom.

Cohen (1994) claims that when "students work together in a small group then everyone -can participate in a task that has been clearly assigned", while Chiriac (2014) considers the group work as "a way to learn how to think for yourself, as well as developing the students' argumentative abilities and critical thinking within students' collaboration which leads to higher productivity and greater results". Finally, by Groening's (1996) statement "an abstract subject taught through group work becomes comprehensible and easy to understand for students". To generalize these thoughts we think that the group work method gives the opportunity to better develop student's learning skills and abilities and helps students to gain more knowledge.

\section{REVIEW OF THE RELATED LITERATURE}

As one of the most spoken languages in the world, English has become an international language. In order to improve international presence, some developing countries have focused on enhancing the English teaching and learning as a 
foreign language (EFL) from an early age. And Douglas Fuchs (2010) emphasizes that group work covers a multiplicity of techniques in which two or more students are assigned a task that involves collaboration and self initiated language. It implies small group work, that is, students in groups of perhaps six or fewer". In other words we think that collaboration is the powerful mechanism to make students work together for achieving the common goals. Collaborating in a group, a person has to think not only about his/her own benefit, but also for the welfare of those who work with him/her. For many years school education in Kazakhstan was based on the principles of individualism and competition (State program of education development in the Republic of Kazakhstan for 2005-2010, 2004) which is quite unilateral. It is obvious nowadays that student- centered learning is best to allow the student achieve his/her major personal success, which is opposed to failure of another student. Of course, the ability to work independently and achieve the goals is very important. But we are called to prepare children for life in the adult world, where today the ability to cooperate together, making decisions and solving tasks acquires a big role.

Vancouver teacher Helen Hait (2004) claims that "group work is a key structure in supporting and building a community in the process of learning and growing together". After studying the group work in action with her fifth and sixth graders, H. Hait (2004) has come to the conclusion that students must be taught how to work together. Although group work with this class resulted in misunderstanding, anger with each other, arguing, and other inappropriate interactions, "H. Hait (2004) agues, that it was through these social situations that training in proper responses to each other was facilitated". Moreover, the students work very hard at learning polite and respectful ways of interacting. Here Helen Hait (2004) notes that "how thrilled she was with their progress in helping each other more, using respectful words and voice tones, demonstrating care toward each other and monitoring their own tendencies to criticize each other".

A special teaching context is that of an individual student working alone with a teacher over a period of hours or weeks in what are often referred to as "private classes". Such one - to - one teaching is extremely popular, especially for business students. But it is also ideal for students who cannot fit into normal school schedules or who are keen to have individual attention rather than being part of a group. In this context we support David Johnsons' idea (1992) that "teacher and student can tailor the course to exactly what is appropriate for that one student, rather than having to reach a compromise based on what is suitable for a group as a whole". D. Johnsons (1992) further states that "this has enormous advantages not only for the designing of a program of study where the syllabus and content can be matched to a particular student's needs and interests, but also in terms of the student's learning style and what kind of stimulus they respond to best". Moreover, it seems that one - to - one students get greatly enhanced feedback from their teachers. 


\section{THE DISTINCTION BETWEEN GROUP WORK AND INDIVIDUAL WORK}

Group work and individual work have similarities and differences.

Time Requirement

Zhaitapova and F. Nametkulova (2013) consider that "teachers' preparation time

differs in collaborative and individual activities, as does the time students invest". Individual learning lets students to work at their own pace, which has positives and negatives. Some students will finish quickly and either feel accomplished or be bored in class. Others may not finish in class and plan to finish at home. Additionally, individual learning requires students to manage their time, which some students may not handle well. Teachers should spend time teaching learning skills if necessary and should always provide structure with individual learning. As Jeremy Harmer (2001) comments "teaching collaborative learning takes planning, maybe more in the secondary setting". Elementary and middle school students are often eager to work together, but high school students may be wary of doing so. Teachers have to explain expectations and assign different roles for each group member. Teachers also monitor students so they stay on task. Students may work faster than they do individually because they have more help. They could work slower, however, if the group does not function well or if some members need extra explanations.

\section{Role of Homework in Collaborative Learning}

According to scholars' considerations (David W. Johnson, \& Roger T. Johnson 1998) teachers typically assign different types of homework for individual and collaborative groups. One reason is because of ease and another deals with fairness. It is easier for teachers to assign homework to individuals because the students only depend on themselves to finish the assignment. Since only one person is working, the assignments are reasonable. So, students can individually ask for help and students cannot copy off a group member. In collaborative learning, students depend on others for help, which is a great benefit, unless they take advantage of that.

In collaborative learning, homework consists of larger assignments. Too often collaborative groups do not work fairly, and one or two students do the work. Collaborating outside the classroom is also a struggle, as students may not be able to meet. If the organization of the process is done properly, groups are proud of their finished assignment and have learned important skills for working with others. Even though group work is regarded in whole as a useful students' learning tool, practice shows that students work at different speeds, i.e. some students may dominate the group while the rest could deviate from the discussion topic. In this context the use of grading assignments might be considered.

\section{Grading}

Katharine Davies Samway and Dorothy Taylor (2008) point out several thoughts that "grading assignment from individual learning is normally straight- 
forward. Students should know how teachers grade and what is expected of an assignment. Teachers are normally comfortable grading individual work". It is obvious that collaborative projects may cause snags when grading. Some students may have not worked equally, the project may be only partially complete or only part may be done correctly. Rubrics should address such issues. Rubrics can have a section for individual participation. Some teachers are comfortable allowing group members to evaluate each other for consideration in grading. It is worth noting another difference from individual grading is the time invested. Teachers give more explanations for collaborative work than individual, since collaborative work often raises more questions among different people.

\section{ADVANTAGES AND DISADVANTAGES OF GROUP WORK}

According to Ellen Sarkisian (1997-2010) "group work has some advantages and disadvantages: group works are an ideal situation, theoretically. If everyone follows the rules, they can be beneficial for all involved". Students study well in a group because they are obliged to pull their own weight from the developmental perspective (Hammar Chiriac \& Hempel, 2008; Slavin, 1987, 1990) and also from the motivational perspective (Webb, \& Palincsar, 1996; Slavin, 1987, 1990). They must read the material before getting together, so a group work becomes a deadline to complete revising for a given amount of material. When students get together, they share ideas and hash out problems that would be too difficult for an individual to solve alone. When one student explains a concept to another, he reinforces the concept for himself. Had he been studying alone, he may not have considered the gaps in his knowledge. Studying is useless if the knowledge gained can't be reproduced when required. A group work is beneficial intellectually but also emotionally, as students encourage each other to study.

We think that a group work only works if everyone does their part. In other words, if only the entire group members work together then they could contribute to the acquisition of new knowledge and stimulate learning to promote academic performance. We emphasize this point for teachers to keep in mind that if one student is weak, his presence can be detrimental for everyone else. One loud, rowdy or unprepared student can make it difficult for everyone else to stay on track. Instead of making their way through the course, they often end up trying to motivate that student to keep up. Sometimes it is not one student causing the problem but the group itself. An unmotivated or underprepared group can turn into one long gossip session.

D. Johnsons (1992) comments regarding the advantages and disadvantages of group work as "the advantages of having a group work is that all members are able to share their experiences, share workloads, and you can all test each other. In my own experiences a group work gives a motivation to study and update my readings because most of my buddies give me encouragement. It also helps me to learn new ideas as well as important points I missed on my readings. Most of the members in my group work are very open in sharing what they know". 
D. Johnsons (1992) further claims that "the disadvantage of group work is the part of compelling yourself to attend to it after the class or during your rest days. Commitment among each member is an important aspect in group work. Hence you and your groupmates have to set aside other activities to study together. To join a group work or not is your own choice, because there are other people who learn better when they do it alone. If you think you will be learning effectively in joining or having a group, go on and enjoy the fun way of learning".

Having analyzed the group work from different methodologists and scientists' point of view, we realize that this form of learning brings positive results only in combination with conventional methods. We must not forget that the group work is not entertainment during school hours; it is a full-fledged form of work in the classroom, next, the proper use of which leads to the achievement of certain academic and educational purposes. Finally, the teacher has to do everything possible to students imbued with the understanding that they are not just playing at being adult, but above all learn to work together and improve their level of English knowledge.

\section{METHODOLOGY}

We have developed a purpose-designed questionnaire to assess students' preference for different teaching methods to identify the most ones in English language teaching in Kazakhstan. The purpose-designed questionnaire was completed by 75 participants: 20 pupils (of school lyceum № 56), 35 students and 20 teachers of Gumilyov Eurasian National University, Astana. There are 16 questions with Multiple-choice answers and 1 question with personal opinion. The first 8 questions were addressed to respondents to identify their attitudes regarding the group work of the English language learning, and from 10 to 15 questions were suggested to identify respondents' opinions regarding an individual work of learning. The $9^{\text {th }}$ and $16^{\text {th }}$ questions were concrete questions such as: "Do you find working in a group as an effective method of learning a foreign language?" or "Do you find working individually as an effective method of learning a foreign language?" The $17^{\text {th }}$ question was proposed in order to clarify the personal opinion of each person.

Tab.1 A purpose-designed questionnaire identification the most effective method in English language teaching in Kazakhstan.

\begin{tabular}{|c|c|c|}
\hline English & Kazakh & $\begin{array}{l}\text { Type } \\
\text { of response }\end{array}$ \\
\hline $\begin{array}{l}\text { 1. Do you agree with the statement from a } \\
\text { teacher in Vancouver Helen Hait (2004) that: } \\
\text { "Group work is a key structure in supporting } \\
\text { and building a community in the process of } \\
\text { learning and growing together"? }\end{array}$ & $\begin{array}{l}\text { Сіз Хелен Хайт (2004) мұғалімнің айтқан } \\
\text { ойымен келісесіз бе: “Топпен жұмыс жасау } \\
\text { қоғамды қалыптас-тыруда, білім алуда және } \\
\text { дамытуда ең маңызды структура болып } \\
\text { табылады”? }\end{array}$ & $\begin{array}{ll}\text { - } & \text { Yes } \\
\text { - } & \text { No } \\
\text { - } & \text { Doubt }\end{array}$ \\
\hline $\begin{array}{l}\text { 2. Do you think that a learner can have a } \\
\text { better understanding via group discussion? }\end{array}$ & \begin{tabular}{|l} 
Окушы сабақты топтық талдау барысында \\
жақсырақ түсіне алады деп ойлайсыз ба?
\end{tabular} & $\begin{array}{ll}\text { - } & \text { Yes } \\
\text { - } & \text { No } \\
\text { - } & \text { Doubt }\end{array}$ \\
\hline
\end{tabular}




\begin{tabular}{|c|c|c|}
\hline $\begin{array}{l}\text { 3. Do you contradict the fact that there is } \\
\text { limited time by the teacher for each of the } \\
\text { individual students in a group? }\end{array}$ & $\begin{array}{l}\text { Tоппен жұмыс істеу барысында барлық } \\
\text { оқушыларға көңіл бөлуге мұғалімнің уақыты } \\
\text { шектеулі дегенмен келіспейсіз бе? } \\
\end{array}$ & $\begin{array}{ll}- & \text { Yes } \\
\text { - } & \text { No } \\
\text { - } & \text { Doubt } \\
\end{array}$ \\
\hline $\begin{array}{l}\text { 4. Are grammar rules complicating and } \\
\text { more complex when it comes to working in } \\
\text { a group? }\end{array}$ & $\begin{array}{l}\text { Топпен жумыс жасау барысында оқушыларға } \\
\text { грамматикалық ережелерді түсіну қиынға соға } \\
\text { ма? }\end{array}$ & \begin{tabular}{ll|}
- & Yes \\
- & No \\
- & Doubt \\
\end{tabular} \\
\hline $\begin{array}{l}\text { 5. Do you think that working in a group is } \\
\text { a good method of communicational skills } \\
\text { development? }\end{array}$ & $\begin{array}{l}\text { Коммуникативті қабілеттерді дамыту үшін } \\
\text { топпен жұмыс жасау тиімді әдіс деп ойлайсыз } \\
\text { ба? } \\
\end{array}$ & $\begin{array}{ll}- & \text { Yes } \\
- & \text { No } \\
- & \text { Doubt } \\
\end{array}$ \\
\hline $\begin{array}{l}\text { 6. Do you think it is helpful and faster } \\
\text { studying in a group than individually? }\end{array}$ & $\begin{array}{l}\text { Окушы жалғыз жұмыс жасау барысына } \\
\text { қарағанда, топпен оқыған пайдалы және } \\
\text { жылдамырақ деп ойлайсыз ба? }\end{array}$ & \begin{tabular}{ll|} 
& Yes \\
- & No \\
- & Doubt \\
\end{tabular} \\
\hline $\begin{array}{l}\text { 7. Do you think that sharing of views with } \\
\text { others in group work can increase the } \\
\text { individual's knowledge and exposure to new } \\
\text { information? }\end{array}$ & $\begin{array}{l}\text { Tоппен жұмыс жасау барысында окушылар } \\
\text { бір - бірімен ой - пікірлерін алмасу арқылы } \\
\text { білім деңгейлерін жоғарлатып, окушылар жаңа } \\
\text { ақпаратты меңгереді деп ойлайсыз ба? } \\
\end{array}$ & $\begin{array}{ll}- & \text { Yes } \\
- & \text { No } \\
- & \text { Doubt } \\
\end{array}$ \\
\hline $\begin{array}{l}\text { 8. Do you think that working in a group } \\
\text { can effectively create and increase students' } \\
\text { socialization time? }\end{array}$ & $\begin{array}{l}\text { Топтық жұмыста оқушылар сабаққа қатысты } \\
\text { емес қоғами іс-әрекеттермен уақытты текке } \\
\text { кетіреді деп ойлайсыз ба? }\end{array}$ & $\begin{array}{ll} & \text { Yes } \\
- & \text { No } \\
- & \text { Doubt } \\
\end{array}$ \\
\hline $\begin{array}{l}\text { 9. Do you belief that working in a group } \\
\text { is an effective method of learning foreign } \\
\text { language? }\end{array}$ & \begin{tabular}{|l|} 
Шет тілін оқыту барысында топтық формада \\
жұмыс жасау тиімді тәсіл деп ойлайсыз ба?
\end{tabular} & $\begin{array}{ll}- & \text { Yes } \\
- & \text { No } \\
- & \text { Doubt } \\
\end{array}$ \\
\hline $\begin{array}{l}\text { 10. Do you agree that studying individually } \\
\text { can create self control and confidentiality? }\end{array}$ & $\begin{array}{l}\text { Жеке жұмыс жасау оқушылардың өзін- } \\
\text { өзі дұрыс ұстап, өзіне деген сенімділігін } \\
\text { жоғарлатады деп ойлайсыз ба? }\end{array}$ & $\begin{array}{ll}- & \text { Yes } \\
\text { - } & \text { No } \\
\text { - } & \text { Doubt } \\
\end{array}$ \\
\hline $\begin{array}{l}\text { 11. Is it true that working individually brings } \\
\text { focus and concentration than in a group? }\end{array}$ & $\begin{array}{l}\text { Топтық жұмысқа қарағанда жеке жұмыс жасау } \\
\text { барысында оқушының сабаққа деген зейіні } \\
\text { apтады деп ойлайсыз ба? }\end{array}$ & $\begin{array}{ll}- & \text { Yes } \\
- & \text { No } \\
- & \text { Doubt } \\
\end{array}$ \\
\hline $\begin{array}{l}\text { 12. Does shyness been overcome and } \\
\text { eradicated studying individually than in a } \\
\text { group? }\end{array}$ & $\begin{array}{l}\text { Окушы жеке білім алу барысында ұялу сезімін } \\
\text { жеңе біледі деп ойлайсыз ба? }\end{array}$ & $\begin{array}{ll}- & \text { Yes } \\
\text { - } & \text { No } \\
\text { - } & \text { Doubt }\end{array}$ \\
\hline $\begin{array}{l}\text { 13. Do you support that clarity come faster } \\
\text { studying individually than in a group? }\end{array}$ & $\begin{array}{l}\text { Tоптық жұмысқа қарағанда жеке жұмыс жасау } \\
\text { формасында оқушы сабақты жылдамырақ } \\
\text { түсінеді деп ойлайсыз ба? }\end{array}$ & $\begin{array}{ll} & \text { Yes } \\
- & \text { No } \\
- & \text { Doubt } \\
\end{array}$ \\
\hline $\begin{array}{l}\text { 14. Do you belief the fact that learning } \\
\text { individually could encourage future } \\
\text { accuracy, motivation, responsibility and } \\
\text { independence? }\end{array}$ & $\begin{array}{l}\text { Жеке білім алу арқылы жауапкершілікті } \\
\text { сезінуге, тәуелсіз болуға және болашақтағы } \\
\text { жұмысына деген дұрыс көзқарасын } \\
\text { қалыптастырады деп ойлайсыз ба? } \\
\end{array}$ & $\begin{array}{ll}- & \text { Yes } \\
- & \text { No } \\
- & \text { Doubt }\end{array}$ \\
\hline $\begin{array}{l}\text { 15. Does working individually bring less } \\
\text { stress? }\end{array}$ & $\begin{array}{l}\text { Жеке жұмыс жасауда стрестік жағдайлар } \\
\text { азырақ болады деп ойлайсыз ба? }\end{array}$ & $\begin{array}{ll}- & \text { Yes } \\
- & \text { No } \\
- & \text { Doubt } \\
\end{array}$ \\
\hline $\begin{array}{l}\text { 16. Is it acceptable that learning foreign } \\
\text { language individually is more effective? }\end{array}$ & $\begin{array}{l}\text { Шет тілін оқыту барысында жеке жұмыс жасау } \\
\text { тиімді тәсіл деп ойлайсыз ба? }\end{array}$ & $\begin{array}{ll}- & \text { Yes } \\
\text { - } & \text { No } \\
\text { - } & \text { Doubt } \\
\end{array}$ \\
\hline $\begin{array}{l}\text { 17. Commentary: } \\
\text { According to the } 9^{\text {th }} \text { and } 16^{\text {th }} \text { questions which } \\
\text { of the two methods do you find effective? } \\
\text { Explain your answers. }\end{array}$ & & \\
\hline
\end{tabular}

\section{Source: Own research.}




\section{FINDINGS}

Students' preference from the given choice of forms of learning

Based on a purpose-designed questionnaire results, we have made the pie-chart diagram (Fig.1) to identify more preferred forms of learning for respondents. The pie-chart diagram is composed of four parts of different colors: blue, green, vinous and purple aimed to identify the percentages of each method.

The recommended answers are: 1 . Individual group; 2. A group work; 3. No answer; 4 . Both of them.

The results of counts are as follows:

1) Individual group (blue part) $-25 \%$

2) A group work (vinous part) $-30 \%$

3) No answers (green part) - 13\%

4) Both of them (purple part) - $26 \%$

The results reveal that most people have chosen the working in a group as an effective method of foreign language learning and teaching. In the $17^{\text {th }}$ question people gave the explanations of their choice.

Most of them prefer working in a group, and explain this by the fact that group work improves students intellectually; a student can benefit in many ways from group discussion working together. Next, he can tackle a question to everyone and get a solution from his friends. Then, one can improve the listening skills by debating and working together. Finally, students benefit from studying in groups because they can generally learn faster than students who work alone.

A group work is when all members are able to share their workloads, experiences and they can all test each other. That's why a group work gives a motivation to study. The learners can understand the theme of the lesson through his friends by discussing. Studying with friends it means studying from friends. If they don't understand tasks, they can ask their friends. Also, studying with friends means studying harder. No one wants to be the worst student in the group. That's why they try to do their best to be as good as his friends.

Fig.1. The pie-chart diagram is to identify the percentages of each preferred method.

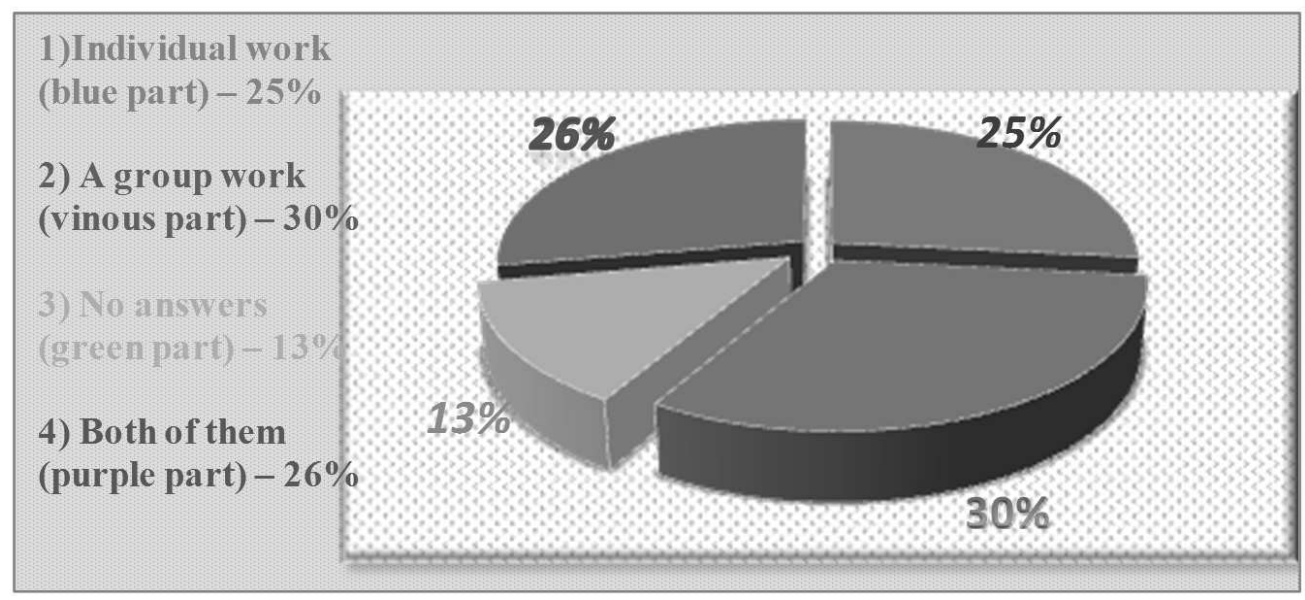

Source: Own research. 
Representatives' preference reflection from the given choice of forms of learning

The analysis of findings given in Figure 2 focuses on the representatives' reflection on what preferred form of learning could have led them to be more effective and dilemmas as well. When analysing the data, all paper-based responses were arranged under three categories marked by different colours to identify each group representatives. They are: the $1^{\text {st }}$ category - Pupils; the $2^{\text {nd }}$ category - Students; the $3^{\text {rd }}$ category - Teachers. The recommended choice of answers was: 1. Individual group; 2 . Group work; 3. No answer; 4 . Both of them.

From pupils' responses (the $1^{\text {st }}$ category), it appeared that both, i.e. group and individual work methods had positive effects on their academic development, belief in self, confidence, personal growth and specific knowledge improvement. Thus, the high percentage of pupils' preference of 35\% was given to 1) individual work; then $30 \%$ to 2 ) both of them, i.e. group and individual work; further goes $25 \%$ to 3 ) group work and finally $-10 \%$ to 4 ) no answer.

From students' responses (the $2^{\text {nd }}$ category), it appeared that group work method was viewed as an opportunity to advance, exchange, share, listen to and value peer opinions. Some students expressed the view that group work had certainly positive effects and not only encouraged them to talk in English but helped to form the most valuable skills as thinking/problem solving and teamwork. For example, student N1 mentioned that "during the group work discussion, I have learned not only to express my ideas, but also listen to and value my groupmates' ideas". The same opinion was held by most of the students, that they could be empowered to become active, confident, and successful group members. They also explained it in the $17^{\text {th }}$ question with the fact that the members of the group were motivated by each other. This is the biggest advantage. In addition, students confirmed that they could generally learn faster than those who worked alone. Further, four students emphasized that work group encouraged them to navigate cultural differences, respect unfamiliar viewpoints, and value participation in academic communication. Moreover, some students expressed their thoughts that they could clarify their doubts by discussing the matter among themselves.

It is obvious, that if one of the members is well versed with a particular subject or topic, he/she can explain the same to the group. This will save lots of time and it will benefit the student who explains the topic to the group.

Thus, the high percentage of students' preference of $46 \%$ was given to 1) group work; then $20 \%$ to 2 ) both of them, i.e. group and individual group work; further goes the same $17 \%$ to 3 ) individual work and 4) no answer.

It is worth noting that only few students preferred to work individually, so it could be considered as disadvantages of individual work. It does not help a class to develop a sense of possessiveness. It does not encourage cooperation in which students may be able to help and motivate each other. When group work is combined with different tasks distribution to individual students, it involves much effort and is time consuming for appropriate materials preparation with comparison to the whole - class teaching involvement.

Thus, when we work with individual students as a tutor or resource, it takes much more time than interacting with the whole class. 
From teachers' response (the $3^{\text {rd }}$ category), it is obvious that most teachers prefer both methods (35\%): group work and individual work. In answers to the $17^{\text {th }}$ question they described some advantages of these methods: for instance, "working together in a group was very good because we had different ideas but these were put together to produce one thing that is richer and stronger. In addition, it is a good method to develop the communication skills. Moreover, studying in a group helps one to learn faster through his/her friends. Then, there will be competition among them and it motivates them to do well. On the other hand, studying individually (30\%) has multiple benefits in academic achievements and also it can help to control himself and create more confidence for each individual. Further, working individually a learner focuses more on his studies, also as one teacher notes: "when you are working alone, you get few ideas, but you are quick to develop them".

Despite of variety of opinions defending on benefits from the group work $(25 \%)$ is thought to generate, a few voices $(10 \%)$ pointed out no answer. It means that there are someone who seemed to be unaware of the learning that was taking place in such long discussions and sometimes heated debates, however difficult an agreement could be to achieve.

Fig.2. The cylinder diagram is to identify the percentages of each categories' representative.

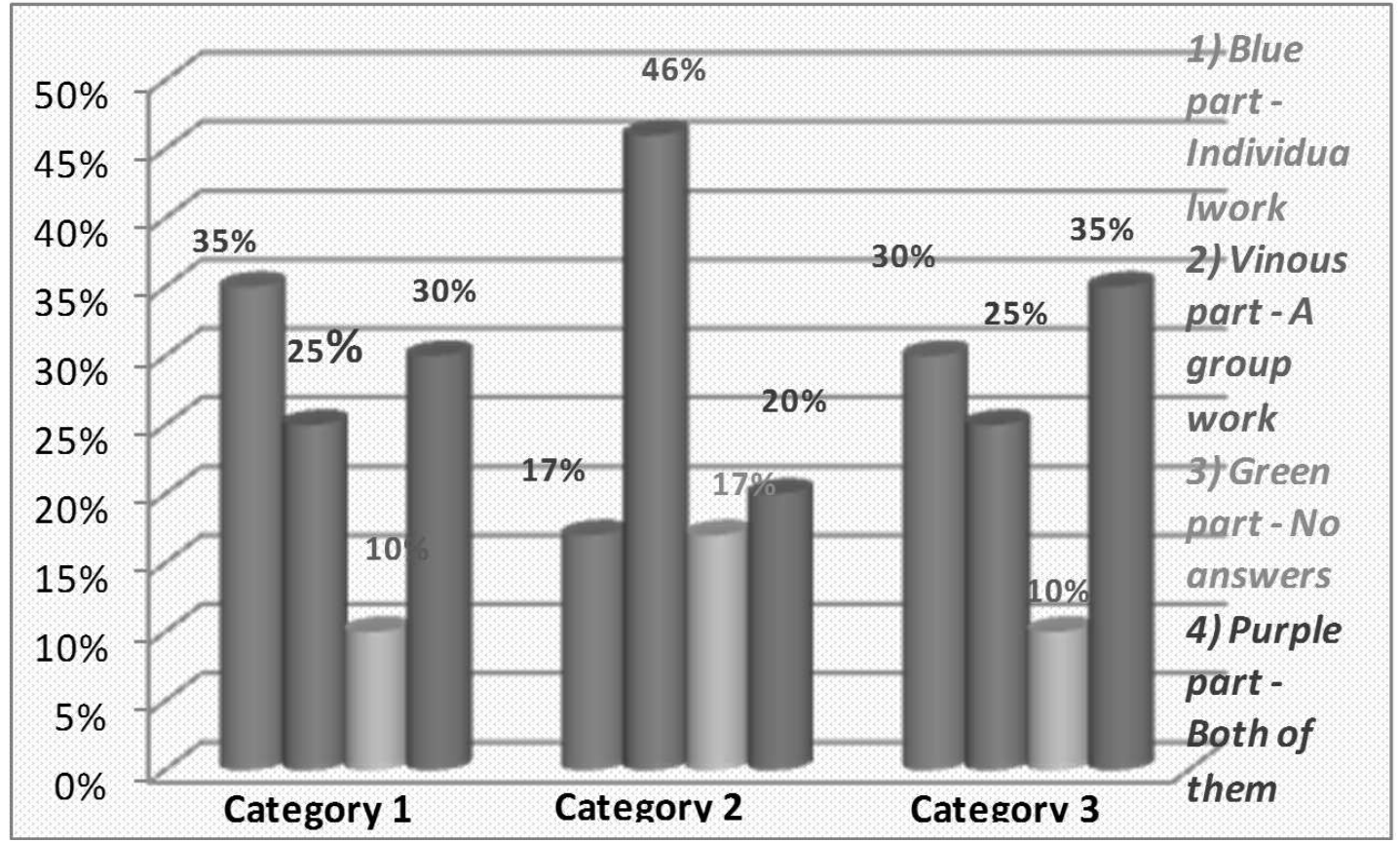

Source: Own research

To summarize, we think that studying is not just reading the content of a book. It involves thorough understanding of the topic, which of course involves good concentration and involvement. This can be achieved either by studying individually or in group. 


\section{RESULTS AND DISCUSSION}

We have analyzed and identified from the findings the implications that the majority of the learners acknowledged having learned in various ways from both group work and individual work methods of English language learning and teaching in Kazakhstan. The purpose-designed questionnaire revealed some problems rose in terms of no answer replies and lack of genuine collaboration among group members and failure to discern what exactly a group work can accomplish in comparison with an individual work.

The survey results present the percentages of each method from each category which is identified. Then, the results describe that some of the students prefer working individually, some of them prefer working in both methods. As for most teachers, they prefer to use both methods: group work and individual work. Almost half of the students prefer to work in a group as well.

Time is the largest difference between individual and group work. Teachers spend more time for planning and grading group work because more things can go wrong. Individual learning is used more often, as it is clear-cut in handling concerns, although group work also has many benefits.

Thus, summarizing the students' different attitudes to the research period, we can state that the advantages of using a group work method is that many students can prepare themselves for class discussion, examinations or class presentations. Students can identify their weak points and learn new ideas to work and study effectively in a friendly and confident environment.

Based on our own experience a group work gives a great motivation to learners to study. It also helps them to learn new ideas, define new ways, appropriate methods as well as to cut out their gaps. Sometimes, it could lead to time waste, if they sit with their groupmates and play like chatting or talking. In this context, if someone wants to cover this subject and other person wants to cover another one, then this could create problem which will distract them from studies.

This paper has examined how individual and group forms of learning of the English language can help to promote collaborative learning among schooling and university students. One added value from this research is that students acknowledged having understood what effective collaboration means and how relevant it is for their learning. As evidence, students admitted having improved their communicative skills and thinking/problem solving and teamwork skills as well through group working. More specifically, students mentioned that they learned to talk, to listen and value peers' opinions along with gained specific knowledge in English, new vocabulary in particular. Finally, there was an issue of knowing if students would have expected from teachers any other support to help them perform better in their learning style and strategy implementing.

\section{CONCLUSION}

To summarise the abovementioned, we have come to the following conclusions. All the advantages and disadvantages of methods, group work and individual 
work, their notions and background which are the crucial aspects of foreign language learning and teaching are effectively identified. The basic general peculiarities of group work and individual work are explored as well.

The distinction between group work and individual work are defined with advantages and disadvantages in both these ways. No two fingers of a hand are same. Similarly, no two individuals can think the same way. This is the key factor in the group work and individual work methods. It is both advantageous and disadvantageous. It is advantageous because differences in people's ways of thinking give rise to many new solutions to the same issue.

Finally, this paper has highlighted the benefits of both group work and individual work as a pedagogical tool capable to stimulate and facilitate students' collaborative and active learning along with individual ones in the English language learning and teaching taken from various types of replies described above which are analyzed and identified.

\section{REFERENCES}

Cohen, E.G. (1994). Restructuring the classroom: conditions for positive small groups. Review of educational research, 64(1), 1-35.

Chirac, E.H., (2014). Group work as an incentive for learning - students' experiences of group work. Frontiers in Psychology, 558(5).

Fuchs, D., Fuchs, L., \& Stecker, P.M. (2010). The "blurring" of special education in a new continuum of general education placements and services. Exceptional children, 76(3), 301-323.

Groening, I. (1996). Learning together - group work in preschools and school. Uppsala: Uppsala University.

Harmer, J. (2001). The practice of English language teaching. Longman Handbooks for language teachers. Malaysia: Eighth impression.

Heit, H., (2004). Effective instruction for creating a classroom community: A brief study of contributing factors in group work. Teaching for social justice. British Scientific Journal. 103(03), 53-63.

Hammar, Ch., \& Hempel, A. (2008). Handbook for group work: Establishing functioning group work in education. Lund: Studentlitteratur.

Johnson, W.D., \& Johnson, R.T. (1992). Learning together and alone: cooperative, competitive, and individualistic learning: Minneapolis: University of Minnesota.

Pica, T. P. (1988). Communicative language teaching: An aid to second language acquisition? Some insights from classroom research. English Quarterly, 90(1), 70-80.

Sarkisian, E. (1997-2010). Working in groups. Derek book center for teaching and learning. Harvard University. Retrieved February 23, 2015, from http://isites.harvard.edu/fs/html/icb.topic58474/ wigintro.html.

Slavin, R.E. (1987). Developmental and motivational perspectives on cooperative learning: Areconciliation. Child Development, 58(5), 1161-1167. Retrieved March 29, 2013, from http:/ / www.jstor.org/ stable/1130612.

Slavin, R.E. (1990). Cooperative learning: Theory, research and practice. Englewoods Cliffs: Prentice-Hall.

State program of education development in the Republic of Kazakhstan for 2005-2010 approved by the President's of the Republic of Kazakhstan order. (2004). No 1459.

Webb, N.M., \& Palincsar, A.S. (1996). Group processes in the classroom. In D.C. Berliner, R.C. Calfee (Eds.), Handbook of educational psychology (pp. 841-873). New York: Macmillan.

Zhaitapova, A.A., \& Nametkulova, F.Zh. (2013). Озық педагогикалық тәжірибені зерттеу әдістемесі [Methodology of the best pedagogical researches]. Open school journal, 8. 